\title{
Distribution of life-history stages of the salp Thalia democratica in shelf waters during a spring bloom
}

\author{
Natasha Henschke ${ }^{1,2, *}$, Jason D. Everett ${ }^{1,2}$, Mark E. Baird ${ }^{2,3}$, Matthew D. Taylor ${ }^{1,2}$, \\ Iain M. Suthers ${ }^{1,2}$
}

${ }^{1}$ School of Biological, Earth and Environmental Sciences, University of New South Wales, Sydney, New South Wales 2052, Australia

${ }^{2}$ Sydney Institute of Marine Science, Building 22, Chowder Bay Road, Mosman, New South Wales 2088, Australia

${ }^{3}$ Plant Functional Biology and Climate Change Cluster, University of Technology Sydney, Sydney,

New South Wales 2007, Australia

\begin{abstract}
Swarms of the salp Thalia democratica periodically occur off southeast Australia following the austral spring bloom of phytoplankton. The present study aimed to determine the abundance and size/stage distribution of $T$. democratica and their relationship with copepods in 3 water types of the western Tasman Sea. Samples were taken from vertical net hauls along 4 cross-shelf transects spaced along $200 \mathrm{~km}$ of the New South Wales coast, from the East Australian Current (EAC) separation zone, around $32.5^{\circ} \mathrm{S}$, to off Sydney $\left(34^{\circ} \mathrm{S}\right)$. Temperature-salinity signatures grouped stations into 3 distinct water types: inner shelf water, EAC and upwelled water. Although common across all stations, T. democratica was significantly more abundant in inner shelf waters compared to both EAC and upwelled water. Analysis of population structure (aggregate buds, aggregate females, aggregate males, immature solitaries and mature solitaries) also identified higher proportions of reproductive aggregates and their offspring in inner shelf water. This salp population structure was significantly different in the EAC regions, characterised by a paucity of the solitary stages, higher temperatures and lower chlorophyll a concentrations. A weak negative correlation was identified between T. democratica and copepod abundance. In the present study, the maximum abundance of T. democratica was twice the highest globally recorded abundance and 10-fold greater than maximum abundances sampled from the continental shelf and slope waters off southeast Australia during the period from 1938 to 1942 .
\end{abstract}

KEY WORDS: Thalia democratica $\cdot$ Salps $\cdot$ Life cycle $\cdot$ Zooplankton $\cdot$ Water types $\cdot$ Population structure East Australian Current

Resale or republication not permitted without written consent of the publisher

\section{INTRODUCTION}

Salps are an ecologically and biogeochemically important class of gelatinous zooplankton. Among the fastest growing metazoans on earth, they can shortcircuit traditional food webs through their ability to continuously filter-feed on a range of particles over 3 orders of magnitude in size (Kremer \& Madin 1992). Salps also alter carbon fluxes within the ocean (Phillips et al. 2008). They produce rapidly sinking faecal pellets that are rich in carbon (up to $37 \%$ ), and it has been suggested that salps can quickly contribute to the vertical transport of carbon, up to $88 \mathrm{mg} \mathrm{C} \mathrm{m} \mathrm{m}^{-2} \mathrm{~d}^{-1}$ (Perissinotto \& Pakhomov 1998), an amount 10-fold greater than the average daily flux in areas without salp swarms (Fischer et al. 1988).

Swarms of the salp Thalia democratica periodically occur in continental shelf waters off southeast Australia during the austral spring and summer (Thompson 1948, Heron 1972a, Deibel \& Paffenhofer 2009). High densities of $T$. democratica have also reoccurred in the Californian Current (Blackburn 1979), west 
Mediterranean (Licandro et al. 2006) and South Africa (Gibbons 1997). Occasional swarms of gelatinous species, including salps, are well known historically, but recent reports indicate that these are increasing in frequency and magnitude as a result of human-induced stresses such as eutrophication and climate change (Hay 2006).

Salp swarms are possible as a result of their life cycle involving the obligatory alternation between aggregated sexual and solitary asexual generations (Fig. 1), allowing Thalia democratica populations to grow exponentially while maintaining genetic variability (Godeaux et al. 1998). The aggregate stage begins life as a chain of genetically identical individuals ('buds' or A1) and reproduces sexually. Born female, aggregates separate and are externally fertilised immediately after release from their parent, and an embryo grows internally (A2). Once the embryo is born, female aggregates develop testes and function as a male (A3). These males (A3) then fertilise the recently released buds (A1) before dying shortly thereafter. The embryo is the start of the solitary generation (S1) that asexually produces up to 3 chains, each with between 20 and 80 individual aggregates (A1). Once mature (S2), solitaries release each chain separately (Heron \& Benham 1985).

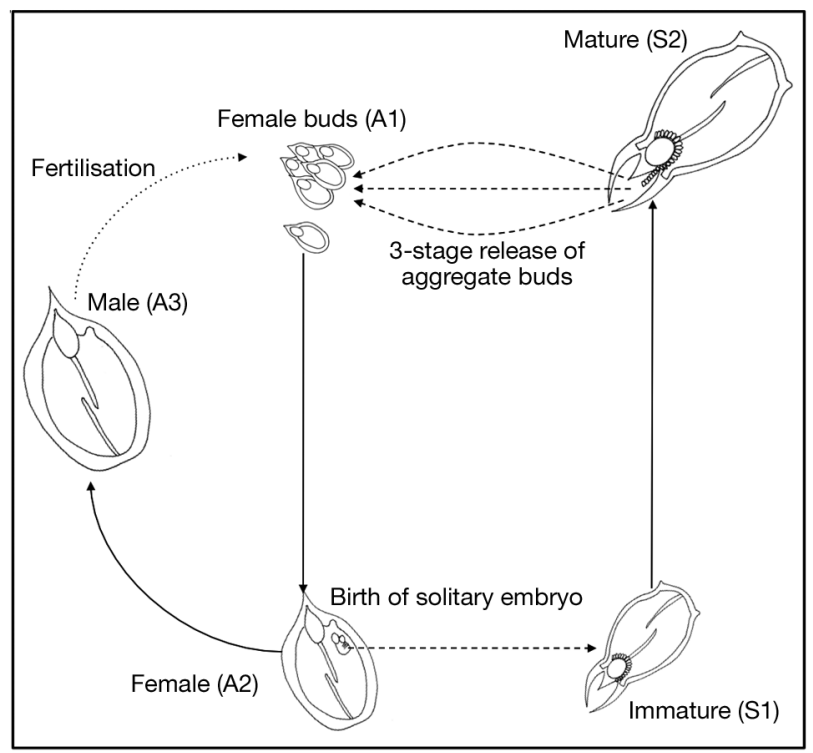

Fig. 1. Life cycle of the salp Thalia democratica, demonstrating alternation between aggregated sexual (A1 to A3) and solitary asexual (S1 and S2) generations (Heron \& Benham 1985). Aggregate female buds (A1) are fertilised immediately upon release by mature male aggregates (A3). These female buds then grow an embryo internally (A2). Once the embryo is born, the aggregate female develops testes and functions as a male (A3). The embryo is the start of the solitary generation. The immature solitary (S1) develops up to 3 chains of between 20 and 80 aggregate buds, released by mature solitaries (S2). Dashed lines represent the shift in generation. Dotted line represents external fertilisation
Growth rates of up to $10 \%$ in length per hour (Heron 1972a) and efficient feeding strategies (Vargas \& Madin 2004) also contribute to the high population growth of Thalia democratica. These adaptations appear to have an impact on other zooplankton within the marine community. It has been identified that copepods can be scarce when salps are abundant over an extended period of time (Humphrey 1963, Silver 1975). As salps can consume particles from a wide size range, they can remove copepods through consumption of copepod eggs and small nauplii (Vargas \& Madin 2004), as well as remove enough particulate matter from the water column to exclude copepods (Nishikawa et al. 1995). Although T. democratica has also been reported to have a prey-predator relationship with the copepod Sapphirina angusta (Heron 1973), abundances of $S$. angusta throughout our study were negligible, so their effect on $T$. democratica was not considered.

Blooms of phytoplankton form along the continental shelf of eastern Australia as a result of the upwelling of cool nutrient-rich slope waters (Hallegraeff \& Jeffrey 1993). These slope-water intrusions occur as a result of either current or wind-driven upwelling (for further information see: Roughan \& Middleton 2002). Under upwelling-favourable conditions water can be brought to the surface, resulting in phytoplankton blooms (Cresswell 1994, Baird et al. 2006). Although it has been difficult to relate abundances of Thalia democratica to physical conditions, swarms of $T$. democratica have been commonly associated with processes such as upwelling or slope-water intrusions (Tranter 1962, Heron \& Benham 1984).

The first extensive study of zooplankton in the western Tasman Sea quantified abundance of salps in net tows from 1938 to 1942 (Thompson \& Kesteven 1942). Thalia democratica occurred at $80 \%$ of the 304 stations, although swarming occurred from September to January, the warmer months, and peaked in November (Thompson 1948). Along the New South Wales coast (28 to $37^{\circ} \mathrm{S}$ ), Thompson took 236 samples from a $50 \mathrm{~m}$ to the surface vertical haul with a N70 net (see 'Materials and methods'). The maximum abundance recorded was 350 ind. $\mathrm{m}^{-3}$, with a mean of $16 \pm 40$ ind. $\mathrm{m}^{-3}$.

Other observations of salp swarms off southeast Australia have been recorded. Large swarms of Thalia democratica were observed at the Port Hacking $50 \mathrm{~m}$ station $\left(34^{\circ} 05^{\prime} \mathrm{S}, 151^{\circ} 13^{\prime} \mathrm{E}\right)$ in 1959 and 1960 , with the total zooplankton biomass (dominated by salps) reaching 1187 and $2399 \mathrm{mg} \mathrm{m}^{-3}$ (wet weight) (Tranter 1962). Humphrey (1963) observed a reduction in the spring bloom of phytoplankton as a result of 1959 and 1960 salp swarms. Further salp swarms were observed at the Port Hacking $100 \mathrm{~m}$ station $\left(34^{\circ} 05^{\prime} \mathrm{S}, 151^{\circ} 15^{\prime} \mathrm{E}\right)$ from August to October and in December 1978 (Halle- 
graeff 1981). Young (1989) also found high concentrations of salps on the outside and on the edge of a warm-core eddy (centred at $33^{\circ} 30^{\prime} \mathrm{S}, 153^{\circ} 30^{\prime} \mathrm{E}$ ) in September and October 1979. Recent studies have identified the possibility to predict patches of salps based on meteorological and oceanographic data (Deibel \& Paffenhofer 2009). The initial response of the salp population to oceanographic conditions should be evident in the population structure. Given the unusual life-history stages of $T$. democratica, the quantification of population structure is quite feasible. However, no study has quantified the 2 alternate life-history stages during bloom formation.

In the present study, we determined the spatial distribution and abundance of Thalia democratica in the western Tasman Sea in relation to water types following an austral spring bloom of phytoplankton. We identified hydrographic conditions that support the formation of $T$. democratica swarms by comparing the spatial distribution of size and population structure with water types. We also investigated the relationship between the abundance of $T$. democratica and copepods to examine the ecological impacts of these swarms.

\section{MATERIALS AND METHODS}

Study site. The surveyed area extended off southeast Australia in the Southwest Pacific Ocean, from Broughton Island in the north $\left(32^{\circ} 30^{\prime} \mathrm{S}, 152^{\circ} 30^{\prime} \mathrm{E}\right)$ to Sydney in the south $\left(34^{\circ} \mathrm{S}, 151^{\circ} 30^{\prime} \mathrm{E}_{i}\right.$ Fig. 2). Four transects perpendicular to the New South Wales coast were sampled from 15 to 19 October 2008 aboard the RV 'Southern Surveyor'. These transects were made up of from 6 to 10 equidistant stations and were located with the aid of daily Moderate Resolution Imaging Spectroradiometer (MODIS) and Advanced Very High Resolution Radiometer (AVHRR) satellite imagery. Transects were identified as oceanographic points of interest that were most likely to stimulate strong biological responses. These hydrographic features included a cyclonic eddy off Sydney, continental slope water off Broken Bay and upwelling sites off Stockton Bight and Broughton Island (Fig. 2).

Sampling procedure. At stations along each transect, the vessel's Seabird SBE911-plus conductivitytemperature-depth (CTD) recorder equipped with a Chelsea AquaTracker Mk3 fluorometer was used to

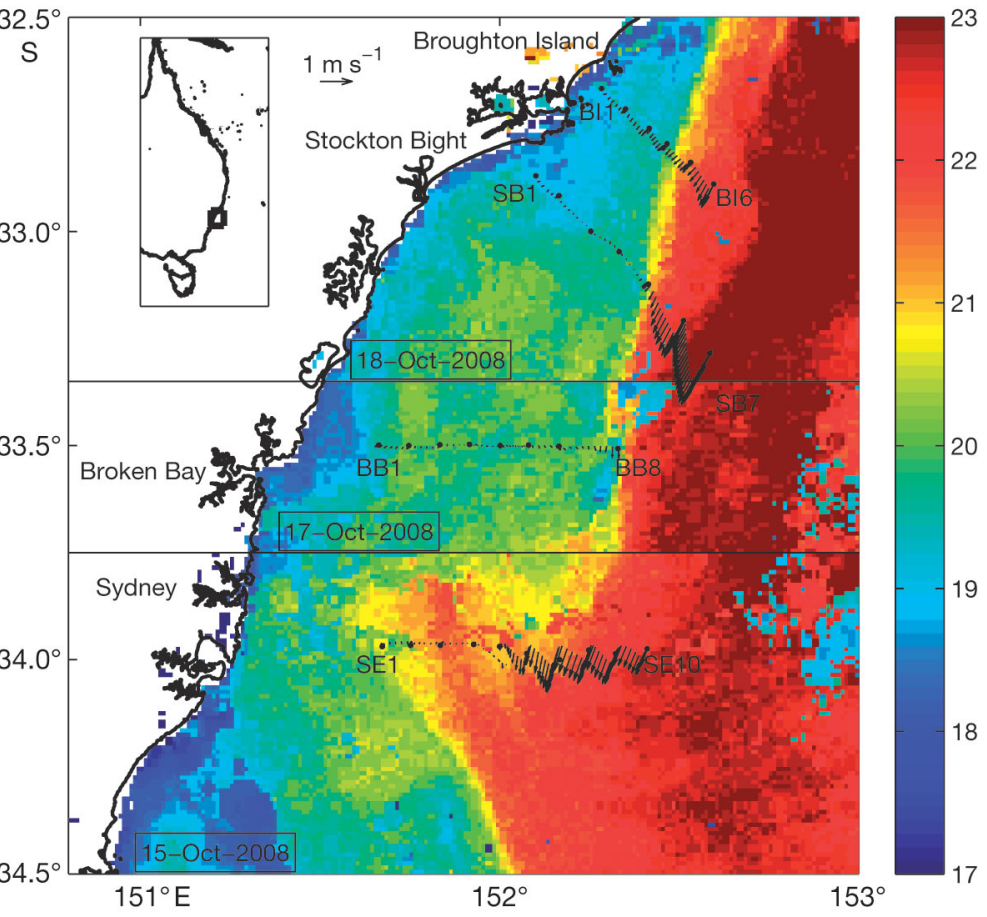

Fig. 2. Study area with sea-surface temperature $\left(\mathrm{SST}_{i}{ }^{\circ} \mathrm{C}\right)$ and surface current vectors overlaid. Dates refer to SST conditions on the day of sampling. Current vectors are shown from the vessel's Acoustic Doppler CurIsland; SB: Stockton Bight. BB: Broken Bay; SE: Sydney Eddy. Mosaic (LBOMST) a $0.01^{\circ} \times 0.01^{\circ}$ gridded composite product. This product is based on a running weighted mean of observations over a $14 \mathrm{~d}$ period, with the most recent observations given the greatest weight. Due to the compilation of multiple satellite sources in the LBoMSST product and llite passes, the oceanographic features are not always displayed exactly at the location of sampling within this image. The SST data for the present study were for within $24 \mathrm{~h}$ of the date shown for the Broken Bay, Broughton Island and Stockton Bight transects. The Sydney Eddy transect data were 1 to $2 \mathrm{~d}$ old

record salinity, temperature and fluorescence. The CTD was mounted on a rosette frame holding $10 \mathrm{l}$ Niskin bottles. Water was collected in the Niskin bottles for chlorophyll a extraction at the surface and the fluorescence maximum. The fluorescence maximum depth was determined as the depth of the maximum fluorescence reading on the downcast. Water was filtered through $47 \mathrm{~mm}$ diameter, $0.7 \mu \mathrm{m}$ Whatman glass fibre filters under low vacuum $(<20 \mathrm{~mm} \mathrm{Hg})$ immediately after collection. The filter papers were then folded, blotted dry, wrapped in aluminium foil and frozen $\left(-20^{\circ} \mathrm{C}\right)$ until laboratory analysis. Chlorophyll a concentration was determined using a Turner Trilogy fluorometer (Turner designs) according to the methodology of Parsons et al. (1984). Fluorescence readings were calibrated against measures of chlorophyll $a$ concentrations from both surface and fluorescence 
maximum depths at each CTD station $(\mathrm{n}=62$, chlorophyll $a=0.1423$ [fluorescence] $-2.967 ; b=0.142, t=$ 8.48, $\mathrm{p}<0.001, \mathrm{R}^{2}=0.55$ ).

To determine the spatial distribution of Thalia democratica, 2 replicate vertical hauls of a N70 net were made at the 31 CTD stations. The N70 net was used extensively during the 1938 to 1942 MV 'Warreen' cruises to sample zooplankton off southeast Australia (Thompson \& Kesteven 1942). The use of the old net design was to facilitate comparison with the most comprehensive earlier study of zooplankton in the region. The N70 net was designed for the capture of medium and smaller size organisms (Kemp \& Hardy 1929) and was modified for the present study to suit modern materials. This modified N70 net had a $70 \mathrm{~cm}$ opening and was made up of 3 sections: a $53 \mathrm{~cm}$ long, $4 \mathrm{~mm}$ mesh section near the mouth (formerly $1 / 4$ inch mesh); a $97 \mathrm{~cm}$ long, $400 \mu \mathrm{m}$ mesh section (formerly silk, 70 mesh/inch); and a $135 \mathrm{~cm}$ long, $225 \mu \mathrm{m}$ mesh section (formerly silk, 200 mesh/inch). The N70 net was hauled vertically from a depth of $50 \mathrm{~m}$ to the surface at a speed of $1 \mathrm{~m} \mathrm{~s}^{-1}$. The samples were collected and immediately preserved in $5 \%$ formaldehyde in seawater. Samples that were collected during either dawn or dusk were not considered in the present study due to synchronised mating aggregations and release of buds that bias observations at those times of day (Heron 1972a,b, Heron \& Benham 1984, Miller \& Cosson 1997).

Laboratory procedure. The methods for calculation of Thalia democratica abundance were based on those of the 'Warreen' cruises (Thompson \& Kesteven 1942). Samples from the N70 net were filtered through a $200 \mu \mathrm{m}$ sieve and concentrated to $100 \mathrm{ml}$ with a $5 \%$ formalin solution. If the concentrated sample exceeded $100 \mathrm{ml}$, a Folsom plankton splitter was used to distribute the sample into 2 jars. The $100 \mathrm{ml}$ sample was gently mixed to ensure an even consistency of organisms suspended in the solution before two $1 \mathrm{ml}$ replicate subsamples were taken with a wide-mouth pipette.

The first 60 Thalia democratica individuals, both aggregate and solitary forms, within each subsample were measured and photographed using image analysis software (Image Pro Plus 5.1; Media Cybernetics). Measurements followed a standard method for the measurement of salps that involved the measurement of salp length from oral opening to the posterior ridge of the gut, exclusive of the outer test (Foxton 1966). A minimum of 100 zooplankton individuals per subsample were counted, with extra subsamples being examined if necessary. Organisms were classified into the following categories enumerating major taxonomic groups known to frequently occur off southeast Australia, following Thompson \& Kesteven (1942): salps, doliolids, crustaceans, larvaceans, chaetognaths, Noctiluca and other zooplankton. In the present paper, only salp and copepod abundance is considered. Further community composition analysis was undertaken by Henschke (2009).

Analysis. Distinctions between water types were based upon a combination of temperature and salinity data obtained from CTD casts, as well as sea-surface temperature imagery (MODIS, AVHRR). Differences among water types were tested with analyses of similarity (ANOSIM). Zooplankton abundance was converted to abundance (individuals per $\mathrm{m}^{3}$ ) using the towed volume. Towed volume was calculated from the mouth area of the net and multiplied by the distance towed $(50 \mathrm{~m})$. Statistical significance was assumed when $\mathrm{p}<0.05$, and normality was assessed through the use of a normal probability plot and the Shapiro-Wilk test (Shapiro \& Wilk 1965). Data were $\log _{10}(x+1)$ transformed if necessary to obtain normal distribution, and the assumption of homoscedasticity was tested with Levene's test. An unbalanced 1-way analysis of variance (ANOVA) was used to test the null hypothesis of no significant difference in Thalia democratica abundance among water types. Tukey's analysis was used for a posteriori pairwise comparisons between factor levels for all ANOVAs.

Analysis of population structure used different lifehistory stages based on length distinctions derived from Heron (1972a) and Heron \& Benham (1985) (Table 1). The Thalia democratica life-history stages

Table 1. Life-history distinctions of Thalia democratica based on classifications identified by Heron \& Benham (1985) and shown in Fig. 1. Duration is based on optimal growth conditions, whereby generation times are as short as 48 h (Heron 1972a)

\begin{tabular}{|c|c|c|c|c|}
\hline Generation & $\begin{array}{l}\text { Life-history } \\
\text { stage }\end{array}$ & $\begin{array}{l}\text { Size } \\
(\mathrm{mm})\end{array}$ & $\begin{array}{l}\text { Duration } \\
\text { (h) }\end{array}$ & Notes \\
\hline Aggregate & $\begin{array}{l}\text { Buds (A1) } \\
\text { Female (A2) } \\
\text { Male (A3) }\end{array}$ & $\begin{array}{l}0-3 \\
3-8 \\
>8\end{array}$ & $\begin{array}{c}5 \\
18 \\
2\end{array}$ & $\begin{array}{l}\text { Released from solitary form } \\
\text { Female form supporting growth of solitary embryo } \\
\text { Male form that fertilises buds upon release }\end{array}$ \\
\hline Solitary & $\begin{array}{l}\text { Immature (S1) } \\
\text { Mature (S2) }\end{array}$ & $\begin{array}{l}0-8 \\
>8\end{array}$ & $\begin{array}{l}24 \\
24\end{array}$ & $\begin{array}{l}\text { Brooding aggregate buds } \\
\text { Released first (of } 3 \text { ) chain of aggregate buds. Subsequent chains } \\
\text { released every } 5 \text { h thereafter }\end{array}$ \\
\hline
\end{tabular}


examined in the present study include: aggregate buds (A1), aggregate females (A2), aggregate males (A3), immature solitaries (S1) and mature solitaries (S2) (Fig. 1, Table 1). For the remainder of our paper, lifehistory stages will be referred to as A1, A2, A3, S1, or S2. Frequency distributions for each life-history stage were used to create a matrix. Matrix data were $\log _{10^{-}}$ transformed to construct the Bray-Curtis similarity matrix. Hierarchal clustering was used to identify common groups of population structure. Similarity profile (SIMPROF) permutation procedure was used to identify the significance of the clusters $(p<0.05)$. To identify the life-history stages contributing most to similarities within clusters, as well as dissimilarity among clusters, similarity percentage analysis (SIMPER) was undertaken. Principal coordinates analysis (PCO) was then undertaken to highlight relationships between clusters and water types.

Regression analyses were used to examine correlations between Thalia democratica abundance and abundances of copepod crustaceans. They were performed with R, Version 2.9.1 (R Development Core Team). Other parametric tests were performed with Predictive Analytics Software, Version 18 (SPSS Inc.), and all multivariate non-parametric tests were performed with PRIMER, Version 6 (PRIMER-E; Clarke \& Warwick 2001, Clarke et al. 2008).

\section{RESULTS}

\section{Hydrological environment}

The EAC is the poleward-flowing western boundary current of the South Pacific. The study site is located in the region where the EAC becomes unstable and the coherent flow of further north develops into a mesoscale eddy field (Cresswell \& Legeckis 1986). Depending on the location of these eddies, the EAC flow in the study region can either be directed in a poleward, along-shore direction, or offshore, as part of the Tasman Front (Baird et al. 2008).

In mid-September 2008, the EAC had a weak flow, with an average temperature range from 20 to $22^{\circ} \mathrm{C}$ and a significant retroflection around $33^{\circ} 30^{\prime} \mathrm{S}$ (Fig. 3a). By the commencement of sampling in October 2008 , the EAC centre had warmed to $23^{\circ} \mathrm{C}$ and a strong eastward flow along the Tasman Front was pre- a) $16 \operatorname{Sep} 2008$

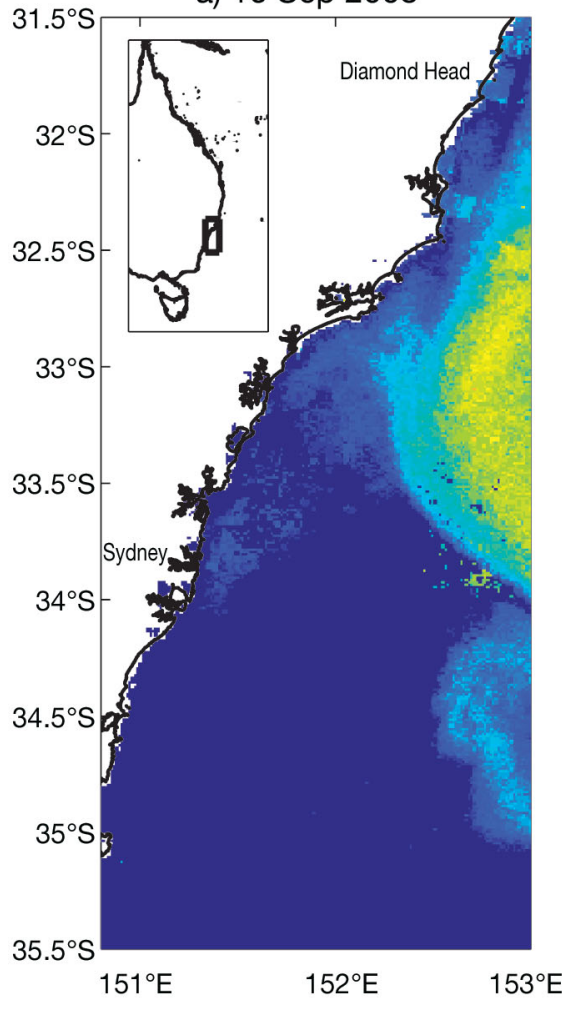

b) 01 Oct 2008

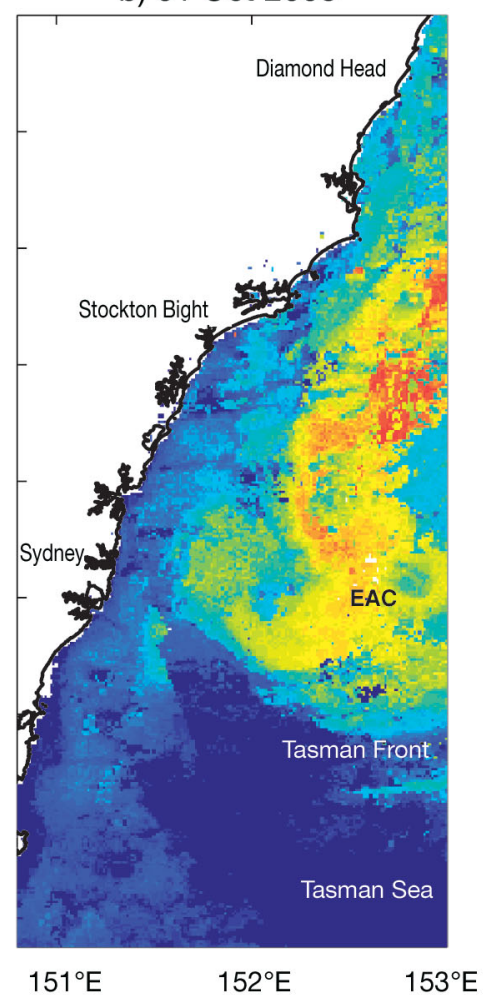

c) 12 Oct 2008

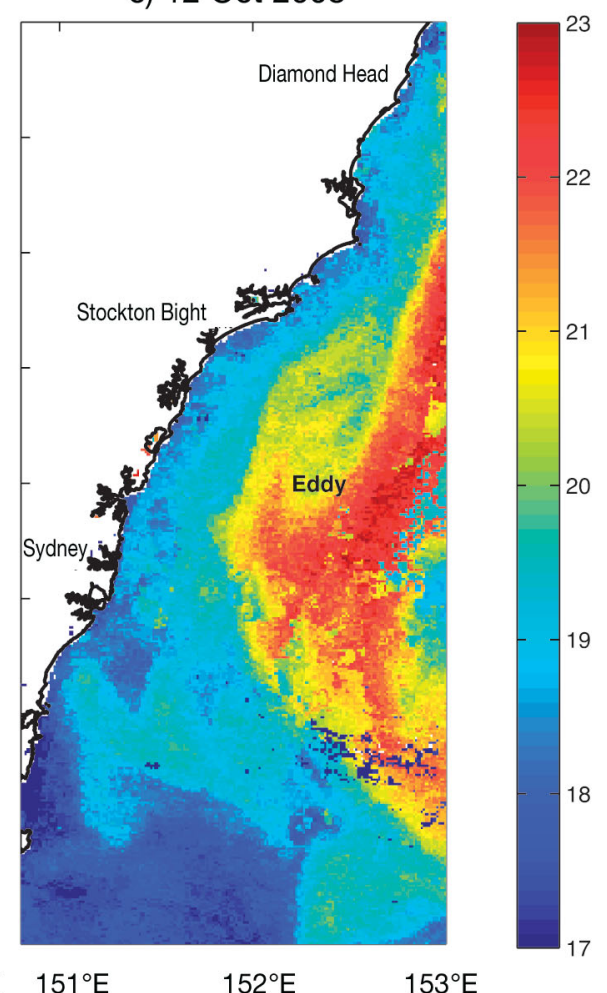

Fig. 3. Study area with sea-surface temperature $\left(\mathrm{SST}^{\circ}{ }^{\circ} \mathrm{C}\right)$ overlaid. Images are given for: (a) 1 mo prior (16 September 2008$)$,

(b) 2 wk prior (1 October 2008) and (c) at the formation (12 October 2008) of the coastal eddy centred at $33^{\circ} \mathrm{S}, 152^{\circ} 30^{\prime} \mathrm{E}$. The locations of the East Australian Current (EAC), Tasman Front, Tasman Sea and the cold core eddy (Eddy) are indicated 
sent (Fig. 3b). The EAC temperature during this time was approximately 1 to $2^{\circ} \mathrm{C}$ warmer than the average over the previous $50 \mathrm{yr}$ (from CSIRO Atlas of Regional Seas [CARS], Version 2006a. For further information see: Ridgway et al. 2002).

A small cyclonic eddy $(40 \mathrm{~km}$ in diameter) formed between 10 and 12 October 2008, north of Sydney at $33^{\circ} \mathrm{S}, 152^{\circ} 30^{\prime} \mathrm{E}$ (Fig. 3c). This eddy was created from a filament of cold upwelled water, and, by 15 October 2008, it had been advected south by the adjacent EAC to $34^{\circ} \mathrm{S}, 152^{\circ} \mathrm{E}$, where the Sydney eddy (SE) transect bisected it (Fig. 2). Due to the EAC meandering adjacent to the Sydney transect, the parallel Broken Bay (BB) transect did not intersect the EAC, only sampling inner shelf water adjacent to the Sydney eddy. On 17 October 2008, a chlorophyll a-rich filament had formed at the Seal Rocks coast $\left(32.5^{\circ} \mathrm{S}\right)$ and extended offshore and southwards along the $200 \mathrm{~m}$ isobath to $33^{\circ} 30^{\prime} \mathrm{S}$. The Stockton Bight (SB) and Broughton Island (BI) transects intersected this filament, as well as the EAC.

The characterisation of 3 water types follows those identified by Cresswell for the region (Plate II in Cress- well 1994): inner shelf water, EAC water and upwelled water (Fig. 4; Table 2). EAC water is advected south from the Coral Sea and is warmer, but also typically fresher, than the surrounding waters (Fig. 2 in Baird et al. 2011; based on the CARS 2006a climatology, for further information see: Ridgway et al. 2002). The upwelled water has been lifted from the continental slope through the interaction of the EAC and the shelf (Roughan \& Middleton 2002) and is therefore cooler and fresher. At the time of sampling, inspection of AVHRR and geostrophic currents (not shown) suggests inner shelf water is composed primarily of an earlier pulse of the EAC that moved onto the shelf in late September. The high salinity of inner shelf water suggests there has been little entrainment of upwelled water or freshwater inputs, although some mixing with saltier waters from further south along the shelf is possible.

During our observations, inner shelf water was more saline than both EAC and upwelled waters. This contrasts with other shelf systems where freshwater inputs often reduce salinity. Off southeast Australia there is little freshwater run-off, and the EAC is generally fresher than the surrounding Tasman Sea waters.

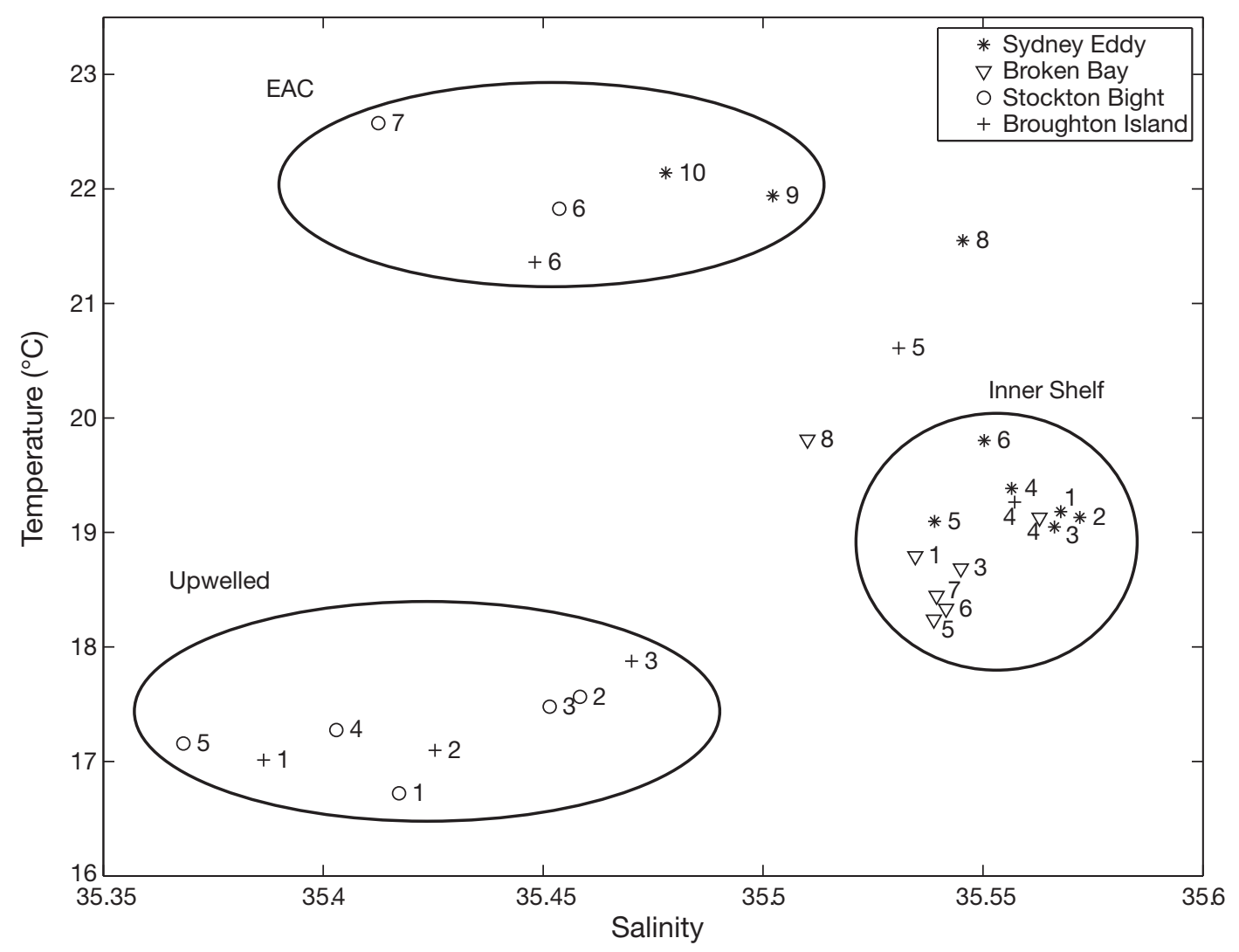

Fig. 4. Temperature-salinity diagram of depth-averaged (to $50 \mathrm{~m}$ ) CTD values from inshore transects. Transects are numbered from west to east (see Fig. 2). Three groups of water types are circled and labelled. Stns SE8, BB8 and BI5 (not circled; $\mathrm{n}=3$ ) were removed from further analysis as they encompassed mixed water. EAC: East Australian Current 
Table 2. Mean characteristics $( \pm \mathrm{SD})$ of the 3 water types identified. Values are depth averaged over the top $50 \mathrm{~m}$ of the water column. The surface mixed layer depth is calculated from the minimum depth at which $T<T(10 \mathrm{~m})-0.4^{\circ} \mathrm{C}$ or $S>S(10 \mathrm{~m})+0.03 \mathrm{PSU}$ following Condie \& Dunn (2006). Stations corresponding to each water mass are labelled. Values in parentheses correspond to ranges. n: number of stations; EAC: East Australian Current

\begin{tabular}{|c|c|c|c|c|c|c|c|}
\hline $\begin{array}{l}\text { Water } \\
\text { type }\end{array}$ & $\mathrm{n}$ & Stations & $\begin{array}{c}\text { Temperature } \\
\left({ }^{\circ} \mathrm{C}\right)\end{array}$ & Salinity & $\begin{array}{l}\text { Surface mixed } \\
\text { layer depth }(\mathrm{m})\end{array}$ & Fluorescence & $\begin{array}{l}\text { Chlorophyll } a \\
\left(\mu \mathrm{g} \mathrm{l}^{-1}\right)\end{array}$ \\
\hline Inner shelf & 13 & BI4; BB1,3-7; SE1-6 & $\begin{array}{c}18.96 \pm 0.45 \\
(18.24-19.80)\end{array}$ & $\begin{array}{c}35.55 \pm 0.01 \\
(35.53-35.57)\end{array}$ & $\begin{array}{l}29 \pm 14 \\
(14-48)\end{array}$ & $\begin{array}{c}29.13 \pm 3.44 \\
(24.12-33.70)\end{array}$ & $\begin{array}{l}1.18 \pm 0.49 \\
(0.46-1.83)\end{array}$ \\
\hline EAC & 5 & SB6-7; BI6; SE9-10 & $\begin{array}{c}21.97 \pm 0.44 \\
(21.36-22.58)\end{array}$ & $\begin{array}{c}35.46 \pm 0.03 \\
(35.41-35.50)\end{array}$ & $\begin{array}{c}41 \pm 6 \\
(32-48)\end{array}$ & $\begin{array}{c}24.95 \pm 6.51 \\
(17.36-35.19)\end{array}$ & $\begin{array}{c}0.68 \pm 0.80 \\
(0-2.04)\end{array}$ \\
\hline Upwelled & 8 & SB1-5; BI1-3 & $\begin{array}{c}17.27 \pm 0.36 \\
(16.72-17.88)\end{array}$ & $\begin{array}{c}35.42 \pm 0.04 \\
(35.37-35.47)\end{array}$ & $\begin{array}{c}19 \pm 12 \\
(4-24)\end{array}$ & $\begin{array}{c}34.73 \pm 2.71 \\
(29.63-37.55)\end{array}$ & $\begin{array}{l}1.97 \pm 0.39 \\
(1.25-2.38)\end{array}$ \\
\hline
\end{tabular}

Water type characteristics were depth averaged over the top $50 \mathrm{~m}$ of the water column to coincide with the zooplankton sampling depth (Fig. 4, Table 2). Stations SE8, BB8 and BI5 were classified as mixed water, as temperature-salinity signatures of these stations were a composite of the 3 previously distinguished water types; thus, they were removed from further analysis. Upwelled waters could be further distinguished from the EAC and inner shelf water by higher chlorophyll $a$ concentrations (Table 2). ANOSIM results further confirmed that each water type was significantly different $(\mathrm{R}=0.96, \mathrm{p}=0.001 ;$ Table 3$)$.

\section{Abundance and horizontal distribution}

Salps were the most dominant zooplankton group in all samples, constituting $59 \%$ of total zooplankton, and

Table 3. Results of analyses of similarity (ANOSIM) among water types. Factors used in analyses were $50 \mathrm{~m}$ depthaveraged temperature, salinity and fluorescence and compared differences between water types. EAC: East Australian Current

\begin{tabular}{|lcc|}
\hline Groups compared & Global R & p-value \\
\hline EAC, Inner shelf & 0.960 & 0.002 \\
EAC, Upwelled & 0.967 & 0.001 \\
Inner shelf, Upwelled & 0.979 & 0.001 \\
\hline
\end{tabular}

this group was comprised exclusively of Thalia democratica. T. democratica aggregates were found across all stations (Table 4, Fig. 5) and were significantly more abundant than solitary forms $\left(F_{1,100}=54.2, \mathrm{p}<\right.$ $0.001)$, with a geometric mean abundance $( \pm \mathrm{SD})$ of $334.29 \pm 6.95$ ind. $\mathrm{m}^{-3}$ compared to $20.84 \pm 6.28$ ind. $\mathrm{m}^{-3}$. Solitaries were absent at BI1 and SE10 (Fig. 5). Both geometric mean aggregate and solitary abundance differed significantly between water types $\left(F_{2,50}\right.$ $\left.=14.3, \mathrm{p}<0.001 ; F_{2,50}=16.5 \mathrm{p}<0.001\right)$. Tukey's post hoc analysis identified significantly greater numbers of aggregates and solitaries in inner shelf water relative to upwelled and EAC waters ( $\mathrm{p}<0.001)$.

\section{Population structure}

Similar trends in population structure were observed across water types (Fig. 6). The abundances of A1 and A2 individuals were significantly greater than abundances of A3 individuals across all water types $\left(F_{2,78}=\right.$ 81.7, $\mathrm{p}<0.001)$, and $\mathrm{S} 1$ individuals were present at significantly higher abundances than S2 across all water types $\left(F_{1,52}=10.7, \mathrm{p}=0.002\right)$.

SIMPER analysis detected the life-history stage contributing most to similarities and dissimilarities among cluster groups. Cluster analysis on life-history stages defined 3 groups that could not be significantly further differentiated ( $p<0.05$; Fig. 7). Cluster A was defined by high proportions of A1 and A2 indi-

Table 4. Abundance (ind. $\mathrm{m}^{-3}$ ) of aggregate and solitary forms of Thalia democratica in Tasman Sea water types during October 2008. n: number of stations; GM: geometric mean $( \pm \mathrm{SD})$; AM: arithmetic mean $( \pm \mathrm{SD})$; EAC: East Australian Current

\begin{tabular}{|c|c|c|c|c|c|c|c|}
\hline \multirow{2}{*}{ Water type } & \multirow{2}{*}{$\mathrm{n}$} & \multicolumn{3}{|c|}{ A goregate - } & & \multirow{2}{*}{$\begin{array}{c}\text { Solitary } \\
\text { AM }\end{array}$} & \multirow[b]{2}{*}{ Range } \\
\hline & & GM & AM & Range & GM & & \\
\hline Inner shelf & 25 & $1044.99 \pm 1.62$ & $1165.09 \pm 551.06$ & $407.35-2344.07$ & $67.99 \pm 2.95$ & $93.08 \pm 59.25$ & $0-245.06$ \\
\hline EAC & 9 & $59.36 \pm 6.06$ & $241.14 \pm 366.97$ & $12.47-916.84$ & $5.67 \pm 5.65$ & $19.17 \pm 28.99$ & $0-81.86$ \\
\hline Upwelled & 16 & $148.92 \pm 10.46$ & $579.23 \pm 619.33$ & 0-1613.83 & $6.83 \pm 5.48$ & $23.50 \pm 48.34$ & $0-196.47$ \\
\hline
\end{tabular}



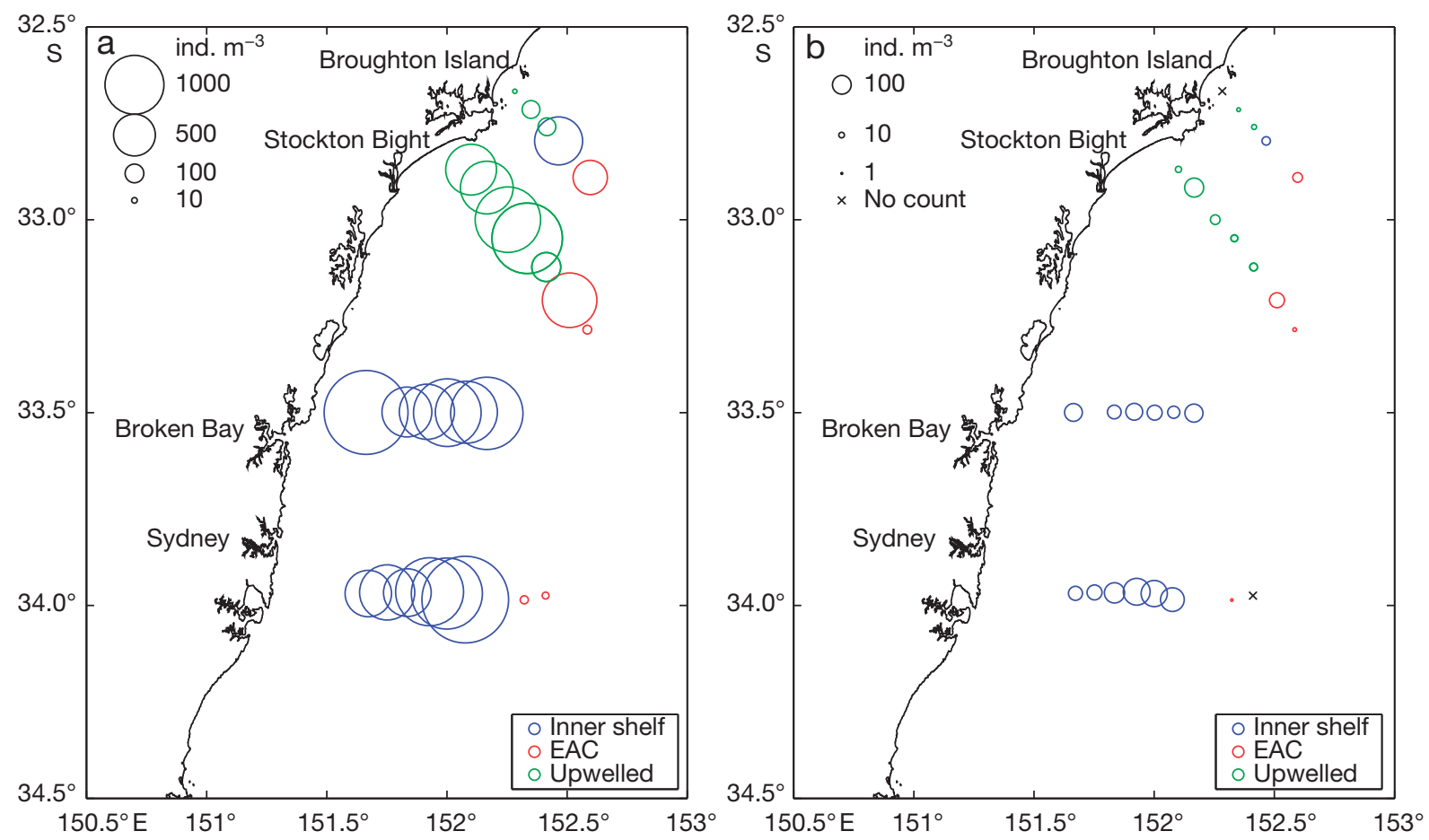

Fig. 5. Abundance distributions of Thalia democratica (a) aggregate and (b) solitary forms (ind. $\mathrm{m}^{-3}$ ). Colours represent water type classifications according to the key. Stations where no individuals were found are also shown ( $\times$ ). EAC: East Australian Current
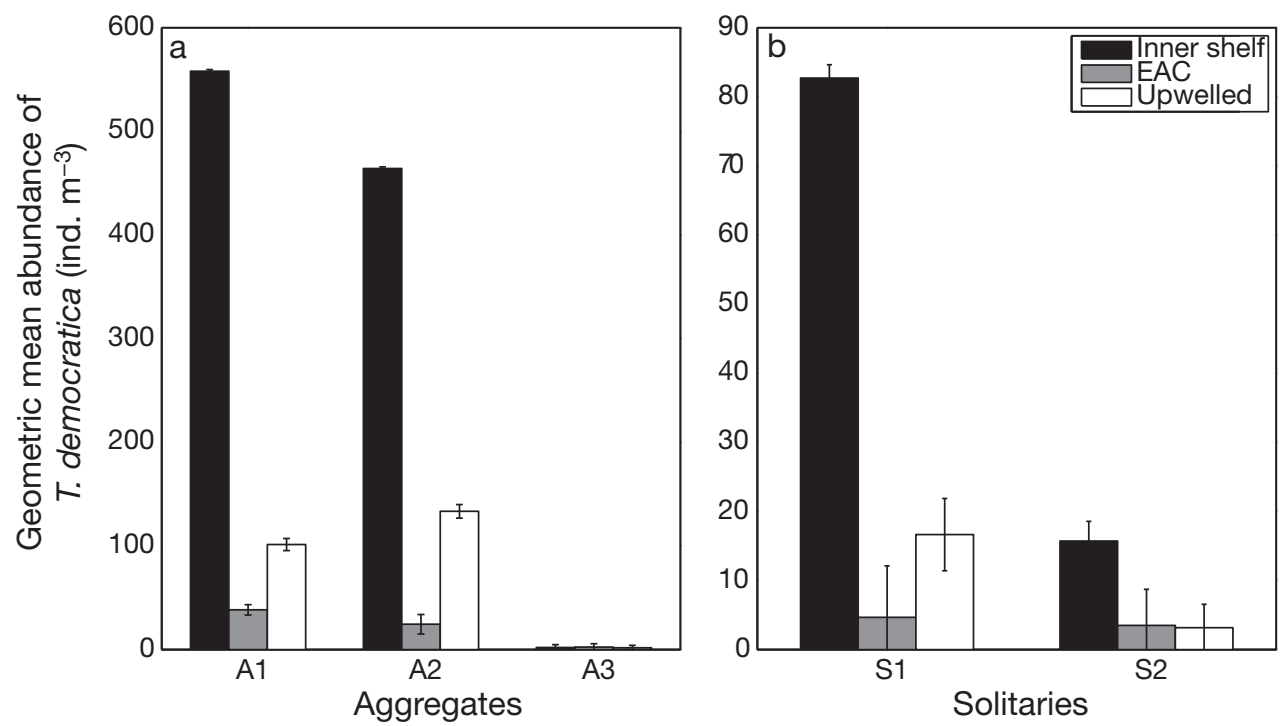

Fig. 6. Geometric mean abundance (ind. $\mathrm{m}^{-3}, \pm \mathrm{SD}$ ) of Thalia democratica (a) aggregate and (b) solitary life-history stages, separated by water type. Refer to Fig. 1 for life-history classifications. EAC: East Australian Current

viduals and minimal proportions of other life-history stages. Clusters B and C were defined by high proportions of A1 and A2 individuals and high proportions of S1 and S2 individuals (Fig. 8). Dissimilarity between Clusters A and C (62\%) and Clusters A and B $(49 \%)$ were driven by the proportion of A2 individ- uals. The dissimilarity between Clusters B and C (25\%) was driven by the proportion of A1 individuals. The cluster groups also differed with abundances. The geometric mean abundance of Thalia democratica (aggregates and solitaries) within Cluster A was $14.55 \pm 1.88$ ind. $\mathrm{m}^{-3}$ compared to $99.30 \pm 2.19$ ind. 


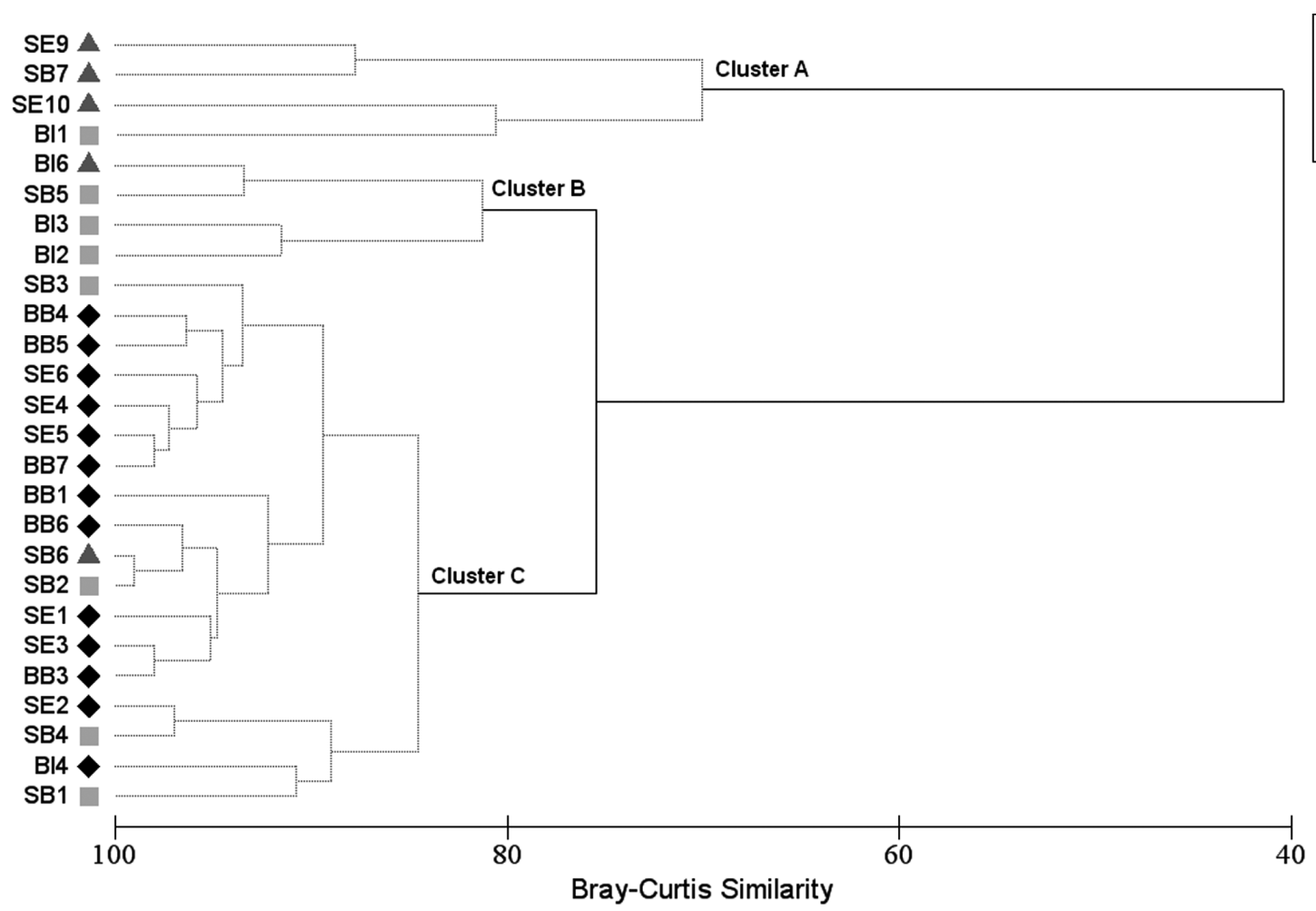

Fig. 7. Cluster analysis of Thalia democratica population structure. Dotted lines connect groups that are not significantly different $(p=0.05)$. Three main cluster groups were identified: Clusters A, B and C
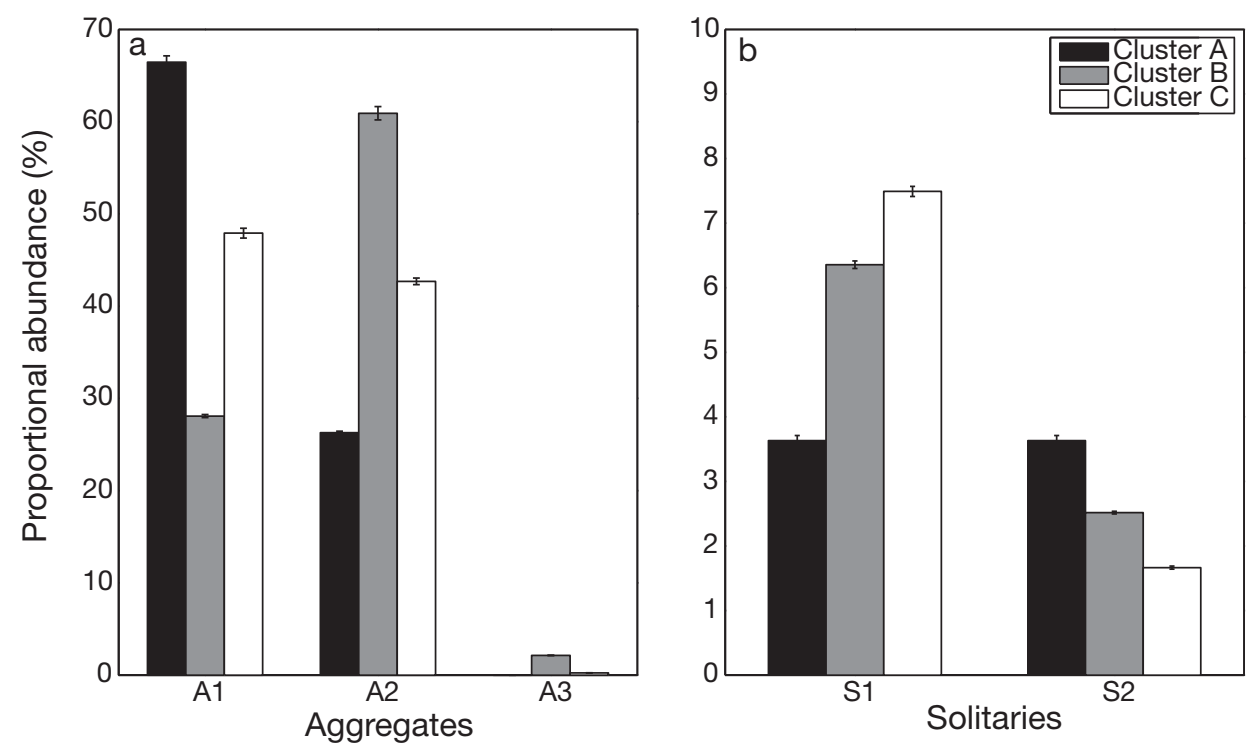

Fig. 8. Proportional abundance of Thalia democratica life-history stages $(\%, \pm$ SD) per cluster group

$\mathrm{m}^{-3}$ and $1010.07 \pm 1.81$ ind. $\mathrm{m}^{-3}$ for Clusters B and $\mathrm{C}$, respectively (Table 5). Water types further distinguished cluster groups. Cluster A was made up mostly of EAC stations $(75 \%)$; Cluster B, by upwelled stations $(75 \%)$; and Cluster $\mathrm{C}$, by inner shelf stations
Water type

$\checkmark$ Inner Shelf

$\triangle \mathrm{EAC}$

Upwelled 


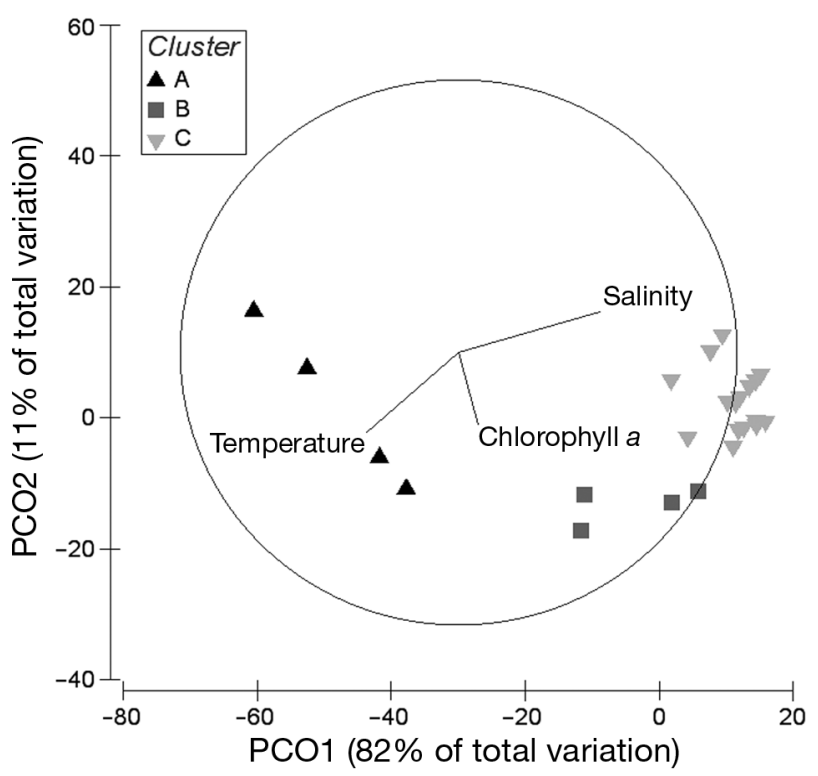

Fig. 9. Ordination of Thalia democratica population structure separated by cluster groups using principal coordinates analysis. Vectors overlaid are multiple correlations of water

type variables (temperature, salinity and chlorophyll a)

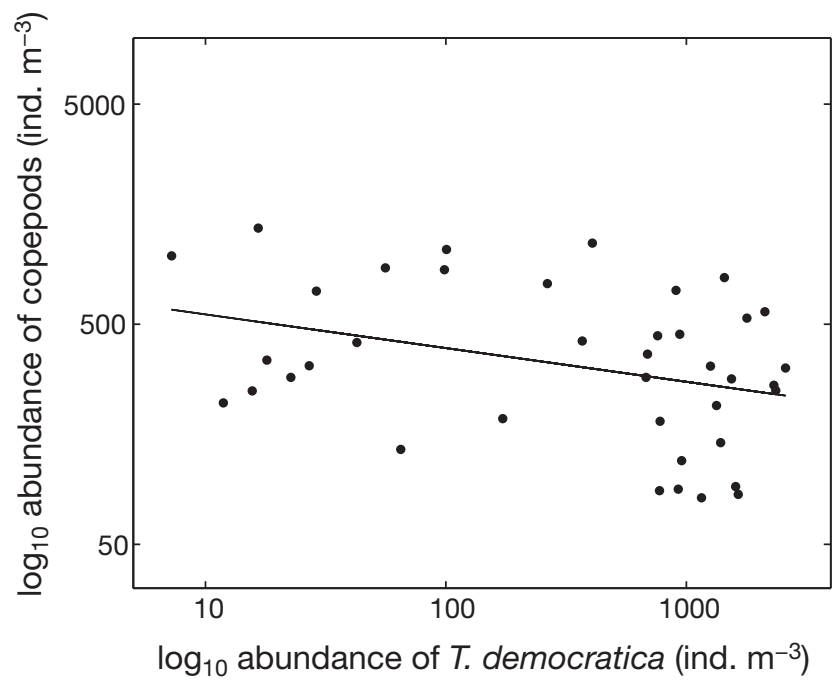

Fig. 10. Regression analysis between $\log _{10}(x+1)$-transformed copepod abundance and Thalia democratica abundance $\left(\mathrm{R}^{2}=0.16\right)$

Table 5. Biological and hydrographic characteristics of cluster groups. Variables include Thalia democratica abundance (GM), temperature, salinity and chlorophyll a. Hydrographic variables are $50 \mathrm{~m}$ depth averaged. GM: geometric mean $( \pm \mathrm{SD})$

\begin{tabular}{|lrccc|}
\hline $\begin{array}{l}\text { Cluster } \\
\text { group }\end{array}$ & GM & $\begin{array}{c}\text { Temperature } \\
\left({ }^{\circ} \mathrm{C}\right)\end{array}$ & Salinity & $\begin{array}{c}\text { Chlorophyll } a \\
\left(\mu \mathrm{I} \mathrm{l}^{-1}\right)\end{array}$ \\
\hline $\mathrm{A}$ & $14.55 \pm 1.88$ & $20.92 \pm 2.62$ & $35.44 \pm 0.05$ & $0.79 \pm 0.94$ \\
$\mathrm{~B}$ & $99.30 \pm 2.19$ & $18.37 \pm 2.02$ & $35.43 \pm 0.04$ & $2.22 \pm 0.14$ \\
$\mathrm{C}$ & $1010.07 \pm 1.81$ & $18.74 \pm 1.13$ & $35.52 \pm 0.05$ & $1.23 \pm 0.55$ \\
\hline
\end{tabular}

\section{Interactions with copepods}

Copepods were the second most dominant zooplankton after Thalia democratica, constituting $23 \%$ of the total zooplankton abundance. Regression analysis identified a negative relationship between T. democratica abundance and copepod abundance $(b=-0.19, t=$ -2.92, $\mathrm{p}=$ 0.025; Fig. 10). No other significant relationship was identified between $T$. democratica and any other zooplankton (Henschke 2009).

\section{DISCUSSION}

This is the first study of Thalia democratica abundance and distribution within the western Tasman Sea in over $60 \mathrm{yr}$. T. democratica constituted $59 \%$ of the total zooplankton sampled, and was the only salp species found throughout sampling (although Thetys vagina was occasionally found in other net types in low numbers). In the present study, the maximum abundance of $T$. democratica (2115 ind. $\mathrm{m}^{-3}$ at BB1) was double the highest globally recorded abundance (1000 ind $\mathrm{m}^{-3}$ ) (Andersen 1998) and almost an order of magnitude greater than maximum abundances sampled from the continental shelf and slope waters off southeast Australia during the period from 1938 to 1942 using similar sampling procedures (Thompson 1948, Baird et al. 2011). Isolated observations of salp swarms, particularly those in 1959 and 1960 (Tranter 1962), during which zooplankton biomass rather than counts of individuals was recorded, may have been of a similar size as the 2008 swarm.

\section{Abundance and horizontal distribution}

Three discrete inshore water types were identified based on satellite imagery and $50 \mathrm{~m}$ depth-averaged temperature-salinity signatures: inner shelf water, EAC water and upwelled water (Fig. 4). Abundances of aggregate and solitary forms of Thalia democratica were significantly greater in inner shelf water compared to other water types. Inner shelf waters were characteristically cooler than the EAC waters, with moderate surface chlorophyll a concentrations (Table 2). Phytoplankton analysis performed during the voyage confirmed higher proportions of diatoms ( $>20$ $\mu \mathrm{m})$ at stations located within the inner shelf water, whereas the EAC stations were dominated by smaller dinoflagellates and prochlorophytes that are indicative of tropical and EAC 
waters (Hassler et al. 2011). Phytoplankton analyses were not undertaken for stations within the upwelled water; however, it has been reported that the frequent upwelling occurring within these stations characteristically promote diatom blooms (Dela-Cruz et al. 2007).

Thalia democratica feeds on a particle range of from $<1 \mu \mathrm{m}$ to $1 \mathrm{~mm}$, but with maximum efficiency on diatoms and ciliates between 20 and $50 \mu \mathrm{m}$ (Vargas \& Madin 2004). This suggests that the differences in abundance of $T$. democratica between inner shelf and EAC water types may be driven by differences in phytoplankton community composition. Despite having a potentially preferable phytoplankton community composition, lower abundances of $T$. democratica were found within upwelled sites. A recent study suggests that there appears to be an inverse correlation between $T$. democratica abundance and phytoplankton abundance off southeast Australia (Deibel \& Paffenhofer 2009). Abundances of $T$. democratica at the chlorophyll a-rich station (SB5; 263 ind. $\mathrm{m}^{-3} ; 3.5 \mu \mathrm{g} \mathrm{l}^{-1}$ ) were almost equal to the maximum abundance calculated between 1938 and 1942 (350 ind. $\mathrm{m}^{-3}$ ) (Thompson \& Kesteven 1942) and were similarly high at other upwelled stations of high chlorophyll a concentrations (Table 4). Some species of salps become clogged in areas of high particulate material, although it is believed that subtle differences in feeding mechanisms or behaviour exist for other species like T. democratica that are able to exploit regions of increased productivity (Harbison et al. 1986). It has been observed that $T$. democratica may be able to regulate food intake when encountering areas of high particulate material by halting feeding or 'backwashing' to expel water (Deibel 1985). A more reasonable hypothesis explaining the lower abundances of salps within the upwelled stations appears to be the 'age' of the water. As the water sampled was upwelled a day earlier (for considerations of time-scales of advection of upwelled water in this region see: Macdonald et al. 2009), it is possible that the salps at these stations had not had enough time to take advantage of the available chlorophyll $a$ resources, resulting in lower abundances compared to those in the inner shelf water. Interestingly, salp populations sampled during the present study in an offshore eddy characterised by old, nutrient-poor water (3 to 4 mo old) had a paucity of solitaries and were in very low abundances (for further information see: Henschke 2009).

\section{Population structure}

Marked zonation between distinct size ranges of Thalia democratica were not found in the present study. This contrasts with findings for populations of
Salpa thompsoni in the Southern Ocean (Kawaguchi et al. 2004), and is most likely due to the rapid growth and short generation times of $T$. democratica. Instead, 3 distinct groups of population structure were identified from cluster analysis. Cluster A was the most distinct, whereas Clusters B and $\mathrm{C}$ were only dissimilar by $25 \%$.

Lower proportions of immature solitaries (S1 individuals) in Cluster A, as well as the absence of reproducing aggregates (A3), indicate slow rates of population growth and incomplete generations. This is also apparent in the density of the Thalia democratica populations, as Cluster A was comprised of stations with the lowest abundance of salps. High population density and abundances of A3 individuals are necessary for successful mating swarms (Heron 1972a). It is not likely that the populations within Cluster A will reach swarm levels, instead they are much like the sparse winter populations identified by Heron and Benham (Fig. 4 in Heron \& Benham 1985).

In Clusters B and $\mathrm{C}$, higher proportions of reproductive aggregates (A2 and A3) and their offspring (S1) suggest faster growing populations and mating success. Similar to the densely populated spring and summer populations (Heron \& Benham 1985), these swarms were predominantly present in inner shelf and upwelled water. The hydrographic conditions that support these successful swarming aggregations were cooler temperatures and moderate chlorophyll a levels (Table 5). This is consistent with long term-trends observed in the Mediterranean Sea, which found significant correlations between increases in Thalia democratica swarm occurrence and cool, diatomdominated waters (Licandro et al. 2006), as well as studies in the central Pacific Ocean (Yount 1958). Despite having similar hydrographic conditions, the salp population within the single upwelled station (BI1) in Cluster A was slow growing. The most recently upwelled station in the present study, as mentioned above, the salp community found at BI1, may not have had enough time to take advantage of the available food resources by the time of sampling.

Temperature has been identified as an important trigger promoting blooms of Thalia democratica within the Mediterranean Sea (Licandro et al. 2006); however, phytoplankton concentration also appears to influence T. democratica growth rates. At $20^{\circ} \mathrm{C}$ and with optimal food abundance, it has been found that $T$. democratica can grow at rates of $10 \%$ in length per hour, completing both generations within $2 \mathrm{~d}$ (Heron 1972a). In contrast, $T$. democratica growth rates $\left(\right.$ at $\left.20^{\circ} \mathrm{C}\right)$ can be as low as 0.3 to $0.9 \%$ in length per hour when food sources are low (Deibel 1982). Based on these observations, it can be hypothesised that the characteristically warm, oligotrophic EAC waters are not suitable for 
supporting the formation of salp swarms. Cluster A stations are more strongly driven by temperature (Fig. 9), and were comprised mainly of EAC stations. Cluster A populations are dominated by A1 and A2 individuals that were produced asexually. This suggests that an optimal food source is needed for growth and maturation of a salp population to include A3, and thus to promote sexual reproduction and successful completion of both generations.

Two EAC stations within this study (BI6 and SB6) were grouped in Clusters B and C, confounding this hypothesis. However, these stations are located on the EAC front, between EAC waters and the inner shelf (Fig. 2) and were characterised by phytoplankton communities indicative of inner shelf waters (higher abundance of diatoms as opposed to tropical communities) (Djajadikarta 2009). This is further supported by the high variability in chlorophyll a concentrations within EAC stations (Table 3) and the PCO analyses indicating that chlorophyll $a$ is more strongly driving differences in Cluster B compared to in Cluster A (Fig. 9). Similarly, previous studies have also identified greater concentrations of salps and other zooplankton at temperature and salinity fronts (Atkinson et al. 1978, Deibel 1982), as fronts are generally thought to have greater phytoplankton abundance than adjacent waters (Graham et al. 2001).

\section{Interactions with copepods}

Despite the dominance of Thalia democratica throughout the majority of stations, abundances of copepods remained high (Fig. 10). The T. democratica population structure across each station illustrated that all populations were relatively young (dominated by A1). As $T$. democratica filtration rates increase with increasing size (Deibel 1985), more mature blooms would have a greater impact on copepod abundances through exploitative competition. Similar results were found in a study by Atkinson et al. (1978), where weak negative correlations were identified between crustacean zooplankton and a recently developed bloom of doliolids. However, enumerating gelatinous zooplankton as individuals to compare with other zooplankton may be misrepresentative due to high water content and size differences. Although it has been found that T. democratica has a tissue density more similar to crustaceans than other gelatinous zooplankton (Heron et al. 1988), more specialised sampling methods are necessary to provide more insight into the ecological impacts caused by salp swarms.

The results of the present study outline the prevalence of Thalia democratica during spring in the western Tasman Sea. It is often difficult to determine accu- rate abundances of salps, as abundance and biomass can fluctuate depending on time of day, growth rate, or presence of mating aggregations (Heron 1972b). As we used identical methods to those used in the 'Warreen' cruises (Thompson \& Kesteven 1942), abundances between studies can be reasonably compared. In our study, $T$. democratica were found to be approximately an order of magnitude more abundant than between 1938 and 1942 (Thompson \& Kesteven 1942), and dominated the zooplankton community. Studies over a larger temporal scale are needed to identify whether abundances of $T$. democratica are increasing, or whether the observed swarm was an extreme event. As our study provides evidence for the potential competition that occurs within the zooplankton community as a result of salp swarms, it is necessary to further examine this theory.

The analysis of population structure was a novel and useful way to identify conditions supporting swarms of Thalia democratica and showed that swarming aggregations of $T$. democratica are dependent upon favourable hydrographic conditions. Within the western Tasman Sea, the inner shelf water appears to be a favourable environment for swarms. By examining the proportions of different life-history stages, one can determine the most sensitive stages driving high abundances, as well as identify the characteristics of the swarm to decide whether it is likely to be slow or fast growing. The present study provides a tool that can help determine the processes influencing the creation of salp swarms. Similar hydrographic conditions occur along other western boundary currents, such as the Gulf Stream or the Kuroshio Current, which also report frequent outbreaks of $T$. democratica swarms (Deibel \& Paffenhofer 2009). As concerns are rising over shifts towards the dominance of gelatinous species within marine ecosystems (Richardson et al. 2009), it is important to examine the effects of increases in salp swarm frequency and occurrence on the marine environment. Implementing the use of population structure will help increase our understanding of the interaction between salp swarm dynamics and oceanographic processes.

Acknowledgements. This research was funded by ARC Discovery Grant DP0880078 held by I.M.S. and M.E.B. The authors thank the captain and crew of the RV 'Southern Surveyor' 10/2008. We especially thank CSIRO scientists: Drew Mills, Pamela Brody and Alicia Navidad for their tireless work keeping the voyage running seamlessly. Peter Oke and David Griffin (CSIRO) prepared satellite and altimetry images during the voyage. Helen Beggs and the Integrated Marine Observing System (IMOS) - an initiative of the Australian Government being conducted as part of the National Collaborative Research Infrastructure Strategy - provided the SST product in Figs. 2 and 3. We acknowledge the generous support of our colleagues at sea and the interest and influence of our anonymous referees. This is Contribution 0051 from the Sydney Institute of Marine Science. 


\section{LITERATURE CITED}

Andersen V (1998) Salp and pyrosomid blooms and their importance in biogeochemical cycles. In: Bone Q (ed) The biology of pelagic tunicates. Oxford University Press, Oxford, p 125-138

Atkinson LP, Paffenhofer GA, Dunstan WM (1978) The chemical and biological effect of a Gulf Stream intrusion off St. Augustine, Florida. Bull Mar Sci 28:667-679

Baird ME, Timko PG, Suthers IM, Middleton JH (2006) Coupled physical-biological modelling study of the East Australian Current with idealised wind forcing. Part I: biological model intercomparison. J Mar Syst 59:249-270

Baird ME, Timko PG, Suthers IM, Middleton JH, Mullaney TJ, Cox DR (2008) Analysis of biological properties across the Tasman Front off south east Australia. Deep-Sea Res I 55:1438-1455

Baird ME, Everett JD, Suthers IM (2011) Analysis of southeast Australian zooplankton observations of 1938-42 using synoptic oceanographic conditions. Deep-Sea Res II 58: 699-711

Blackburn M (1979) Thaliacea of the California Current region: relations to temperature, chlorophyll, currents, and upwelling. CCOFI Rep 20:184-193

Clarke KR, Warwick RM (2001) Changes in marine communities: an approach to statistical analysis and interpretation. PRIMER-E, Plymouth

Clarke KR, Somerfield PJ, Gorley RN (2008) Testing of null hypotheses in exploratory community analyses: similarity profiles and biota-environment linkage. J Exp Mar Biol Ecol 366:56-69

> Condie SA, Dunn JR (2006) Seasonal characteristics of the surface mixed layer in the Australasian region: implications for primary production regimes and biogeography. Mar Freshw Res 57:569-590

> Cresswell GR (1994) Nutrient enrichment of the Sydney continental shelf. Mar Freshw Res 45:677-691

Cresswell GR, Legeckis R (1986) Eddies off southeastern Australia. Deep-Sea Res A 33:1527-1562

Deibel D (1982) Laboratory determined mortality, fecundity and growth-rates of Thalia democratica Forskal and Dolioletta gegenbauri Uljanin (Tunicata, Thaliacea). J Plankton Res 4:143-153

Deibel D (1985) Clearance rates of the salp Thalia democratica fed naturally occurring particles. Mar Biol 86:47-54

> Deibel D, Paffenhofer GA (2009) Predictability of patches of neritic salps and doliolids (Tunicata, Thaliacea). J Plankton Res 31:1571-1579

$>$ Dela-Cruz J, Middleton JH, Suthers IM (2007) The influence of upwelling, coastal currents and water temperature on the distribution of the red tide dinoflagellate, Noctiluca scintillans, along the east coast of Australia. Hydrobiologia 598:59-75

Djajadikarta RJ (2009) Phytoplankton and nutrient dynamics in NSW coastal waters. Honours thesis, University of Technology Sydney, Sydney

> Fischer G, Futterer D, Gersonde R, Honjo S, Ostermann D, Wefer G (1988) Seasonal variability of particle flux in the Weddell Sea and its relation to ice cover. Nature 335: $426-428$

Foxton P (1966) The distribution and life-history of Salpa thompsoni Foxton with observations on a related species, Salpa gerlachei Foxton. Discov Rep 34:1-116

Gibbons MJ (1997) Vertical distribution and feeding of Thalia democratica on the Agulhas Bank during March 1994. J Mar Biol Assoc UK 77:493-505

Godeaux JEA, Bone Q, Braconnot JC (1998) Anatomy of
Thaliacea. In: Bone Q (ed) The biology of pelagic tunicates. Oxford University Press, Oxford, p 1-24

Graham WM, Pagès F, Hamner WM (2001) A physical context for gelatinous zooplankton aggregations: a review. Hydrobiologia 451:199-212

Hallegraeff GM (1981) Seasonal study of phytoplankton pigments and species at a coastal station off Sydneyimportance of diatoms and the nanoplankton. Mar Biol 61: $107-118$

Hallegraeff G, Jeffrey S (1993) Annually recurrent diatom blooms in spring along the New South Wales coast of Australia. Mar Freshw Res 44:325-334

Harbison GR, McAlister VL, Gilmore RW (1986) The response of the salp, Pegea confoederata, to high levels of particulate material: starvation in the midst of plenty. Limnol Oceanogr 31:371-382

Hassler CS, Djajadikarta RJ, Doblin MA, Everett JD, Thompson $P$ (2011) Characterisation of water masses and phytoplankton nutrient limitation in the East Australian Current separation zone during spring 2008. Deep-Sea Res II 58: $664-677$

Hay S (2006) Marine ecology: gelatinous bells may ring change in marine ecosystems. Curr Biol 16:R679-R682

Henschke N (2009) Distribution and population structure of the salp Thalia democratica in relation to water masses of the Tasman Sea. Honours thesis, University of New South Wales, Sydney

Heron AC (1972a) Population ecology of a colonizing species-pelagic tunicate Thalia democratica. 1. Individual growth rate and generation time. Oecologia 10:269-293

Heron AC (1972b) Population ecology of a colonizing species - pelagic tunicate Thalia democratica. 2. Population growth rate. Oecologia 10:294-312

Heron AC (1973) A specialized predator-prey relationship between the copepod Sapphirina angusta and the pelagic tunicate Thalia democratica. J Mar Biol Assoc UK 53: 429-435

Heron AC, Benham EE (1984) Individual growth rates of salps in three populations. J Plankton Res 6:811-828

Heron AC, Benham EE (1985) Life history parameters as indicators of growth rate in three salp populations. J Plankton Res 7:365-379

Heron AC, McWilliam PS, Dalpont G (1988) Length weight relation in the salp Thalia democratica and potential of salps as a source of food. Mar Ecol Prog Ser 42:125-132

Humphrey GF (1963) Seasonal variation in plankton pigments in waters off Sydney. Aust J Mar Freshw Res 14: $24-36$

Kawaguchi S, Siegel V, Litvinov F, Loeb V, Watkins J (2004) Salp distribution and size composition in the Atlantic sector of the Southern Ocean. Deep-Sea Res II 51: 1369-1381

Kemp S, Hardy MA (1929) The ships, their equipment and the methods used in research. Discov Rep 1:141-232

Kremer P, Madin LP (1992) Particle retention efficiency of salps. J Plankton Res 14:1009-1015

Licandro P, Ibanez F, Etienne M (2006) Long-term fluctuations (1974-1999) of the salps Thalia democratica and Salpa fusiformis in the northwestern Mediterranean Sea: relationships with hydroclimatic variability. Limnol Oceanogr 51:1832-1848

Macdonald HS, Baird ME, Middleton JH (2009) Effect of wind on continental shelf carbon fluxes off southeast Australia: a numerical model. J Geophys Res 114:C05016

Miller RL, Cosson J (1997) Timing of sperm shedding and release of aggregates in the salp Thalia democratica (Urochordata: Thaliacea). Mar Biol 129:607-614 
Nishikawa J, Naganobu M, Ichii T, Ishii H, Terazaki M, Kawaguchi K (1995) Distribution of salps near the South Shetland Islands during austral summer, 1990-1991 with special reference to krill distribution. Polar Biol 15: 31-39

Parsons TR, Maita Y, Lalli CM (1984) A manual of chemical and biological methods for seawater analysis. Pergamon Press, Oxford

Perissinotto R, Pakhomov EA (1998) Contribution of salps to carbon flux of marginal ice zone of the Lazarev Sea, Southern Ocean. Mar Biol 131:25-32

Phillips B, Kremer P, Madin LP (2008) Defecation by Salpa thompsoni and its contribution to vertical flux in the Southern Ocean. Mar Biol 156:455-467

Richardson AJ, Bakun A, Hays GC, Gibbons MJ (2009) The jellyfish joyride: causes, consequences and management actions. Trends Ecol Evol 24:312-322

Ridgway KR, Dunn JR, Wilkin JL (2002) Ocean interpolation by four-dimensional weighted least squares - application to the waters around Australasia. J Atmos Ocean Technol 19:1357-1375

Roughan M, Middleton JH (2002) A comparison of observed upwelling mechanisms off the east coast of Australia. Cont Shelf Res 22:2551-2572

Editorial responsibility: Hans Heinrich Janssen, Oldendorf/Luhe, Germany
Shapiro SS, Wilk MB (1965) An analysis of variance test for normality (complete samples). Biometrika 52:591-611

Silver MW (1975) The habitat of Salpa fusiformis in the California Current as defined by indicator assemblages. Limnol Oceanogr 20:230-237

Thompson H (1948) Pelagic tunicates of Australia. Commonwealth Council for Scientific and Industrial Research, Melbourne

Thompson H, Kesteven GL (1942) Pelagic tunicates in the plankton of southeast Australian waters, and their place in oceanographic studies. In: Bulletin 153. Council for Scientific and Industrial Research, Melbourne, p 1-56

Tranter DJ (1962) Zooplankton abundance in Australasian waters. Mar Freshw Res 13:106-142

Vargas CA, Madin LP (2004) Zooplankton feeding ecology: clearance and ingestion rates of the salps Thalia democratica, Cyclosalpa affinis and Salpa cylindrica on naturally occurring particles in the Mid-Atlantic Bight. J Plankton Res 26:827-833

Young JW (1989) The distribution of hyperiid amphipods (Crustacea: Peracarida) in relation to warm-core eddy $\mathrm{J}$ in the Tasman Sea. J Plankton Res 11:711-728

Yount JL (1958) Distribution and ecologic aspects of central Pacific Salpidae (Tunicata). Pac Sci 12:111-130

Submitted: April 1, 2010; Accepted: February 15, 2011

Proofs received from author(s): May 10, 2011 